\title{
Ginsenoside Rb1 Attenuates TGF- $\beta 1$-Induced MUC4/5AC Expression and Epithelial-Mesenchymal Transition in Human Airway Epithelial Cells
}

\author{
Tae Yeong Choi ${ }^{1}$, Joon-Hee Kim ${ }^{1}$, Sooyeon Jo ${ }^{1}$, Sangjae Lee ${ }^{1}$, Hyung-Gyun $\mathrm{Na}^{1}$, \\ Yoon Seok Choi ${ }^{1}$, Si-Youn Song ${ }^{1}$, , Yong-Dae Kim ${ }^{1,2} \mathbb{D}_{\text {, }}$, and Chang Hoon Bae ${ }^{1}$ \\ ${ }^{1}$ Department of Otorhinolaryngology-Head and Neck Surgery, College of Medicine, Yeungnam University, Daegu; and \\ ${ }^{2}$ Regional Center for Respiratory Diseases, Yeungnam University Medical Center, Daegu, Korea
}

\author{
사람 호흡기 상피세포에서 Ginsenoside RB1이 TGF- $\beta 1$ 로 유도된 MUC4/5AC 점액 유전자의 \\ 발현과 상피-중간엽 전이에 미치는 효과 \\ 최태영 ${ }^{1} \cdot$ 김준희 $^{1} \cdot$ 조수연 ${ }^{1} \cdot$ 이상재 $^{1} \cdot$ 나형균 $^{1} \cdot$ 최윤석 ${ }^{1} \cdot$ 송시연 ${ }^{1} \cdot$ 김용대 $^{1,2} \cdot$ 배창훈 $^{1}$ \\ 영남대학교 의과대학 이비인후-두경부외과학교실, ${ }^{1}$ 영남대학교병원 권역 호흡기 전문질환센터 ${ }^{2}$
}

Received March 9, 2020

Revised June 9,2020

Accepted July 1, 2020

Address for correspondence

Chang Hoon Bae, MD, PhD

Department of Otorhinolaryngology-

Head and Neck Surgery,

College of Medicine,

Yeungnam University,

170 Hyeonchung-ro, Nam-gu,

Daegu 45415, Korea

Tel $+82-53-620-3784$

Fax $+82-53-628-7884$

E-mail baich@med.yu.ac.kr
Background and Objectives Ginsenoside Rbl is the main metabolite of Panax ginseng. It is known to have many beneficial properties including anti-inflammatory, antitumoral and antioxidant effects. However, the therapeutic effects of ginenoside Rb1 on inflammatory airway diseases have not been elucidated. Therefore, we investigated the effects of ginsenoside Rbl on the TGF- $\beta 1$-induced mucin gene expression and epithelial-mesenchymal transition (EMT) in human airway epithelial cells.

Materials and Method We evaluated the effects of ginsenoside Rb1 on the changes of MUC4, MUC5AC, occludin, claudin 4, claudin 18, neural (N)-cadherin, and epithelial (E)-cadherin expression by TGF- $\beta 1$ in NCI-H292 cells using reverse, real-time polymerase chain reaction, enzyme-linked immunosorbent assay, and western blot.

Results TGF- $\beta 1$ significantly increased MUC4/5AC expression. Rb1 inhibited TGF- $\beta 1$ - induced MUC4/5AC expression. In addition, TGF- $\beta 1$ significantly attenuated occludin, claudin 18 , and E-cadherin expressions but induced claudin 4 and $\mathrm{N}$-cadherin expressions. On the other hand, Rbl reversed changes in the TGF- $\beta 1$ - mediated expressions of cell junction molecules. Conclusion These results suggest that ginsenoside Rb1 attenuates TGF- $\beta 1$-induced MUC4/ 5AC expressions and EMT in the human airway epithelial cells. These findings are important data demonstrating the potential of ginsenoside $\mathrm{Rbl}$ as a therapeutic agent for inflammatory airway diseases.

Korean J Otorhinolaryngol-Head Neck Surg 2021;64(4):232-9

Key Words Airway epithelial cells · Epithelial-mesenchymal transition · Ginsenoside Rbl · MUC4 · MUC5AC.

\section{서 론 \\ 점액의 과분비는 염증성 호흡기 질환 악화의 중요한 병인 \\ This is an Open Access article distributed under the terms of the Creative Commons Attribution Non-Commercial License (https://creativecommons.org/licenses/by-nc/4.0) which permits unrestricted non-commercial use, distribution, and reproduction in any medium, provided the original work is properly cited.}

중 하나로 이를 해결하기 위해 많은 연구들이 활발히 이루어 지고 있다. 그러나 아직까지 점액 과분비에 대한 명확한 기전 에 대한 이해와 효과적인 치료제의 개발이 부족한 실정이다. 점액의 성상은 점액 유전자에 발현 양상과 깊이 관여되어 있 으며, 염증성 호흡기 질환에서 다양한 양상의 점액 유전자의 과발현이 관찰되는 것으로 알려져 있다. ${ }^{1,2)}$ 점액 유전자는 현 
재까지 20여 개가 발견되었고, 이 중 막결합형 점소인 MUC4 와 분비형 점소인 MUC5AC는 다양한 염증성 호흡기 질환에 깊게 연관되어 있는 대표적인 점액 유전자로 알려져 있다.34)

호흡기 상피 세포 간의 결합은 기도를 보호하는 데 중요한 역할을 하는 것으로 알려져 있으며, 이러한 세포 간의 결합에 는 밀착연접(tight junction), 접착연접(adherens junction), 데스모솜(desmosome), 헤미데스모솜(hemidesmosome), 간 극연접(gap junction) 등이 관여하는 것으로 알려져 있고, 다 양한 염증성 매개물질과 독성물질 등에 의해 세포연접(cell junction)이 약화되거나 손상되면 상피-중간엽 전이(epithelial-mesenchymal transition, EMT)가 발생하게 된다. ${ }^{5,6)}$ 이는 최근 천식이나 만성폐쇄성 폐질환과 같은 염증성 호흡기 질환 악화의 중요한 병인 중 하나로 밝혀지고 있다. ${ }^{7-9)}$

염증성 호흡기 질환의 치료제 중 가장 널리 사용되는 스테 로이드는 점액의 과분비 및 상피-중간엽 전이를 억제하는 효 과가 보고된 강력한 항염증 약물이다. ${ }^{10}$ 그러나 다양한 부작 용으로 인해 사용이 제한되고 장기간 사용이 어려워 여전히 한계점으로 남아있어 스테로이드를 대체할 치료제에 대한 필요성이 대두되고 있다. 인삼 사포닌(ginsenoside)의 활성화 산물 중 하나인 Rb1은 항염증과 항당뇨, 항암, 항산화 등을 포함한 다양한 생물학적 작용을 가지고 있어 다양한 질환에 서 치료효과가 보고되고 있다. ${ }^{11-15)}$ 하지만 아직까지 호흡기 점액 유전자 발현과 상피-중간엽 전이에 미치는 효과에 대해 서는 알려진 것이 거의 없다. ${ }^{15}$ 저자들은 NCI-H292 세포에서 $\mathrm{Rb} 1$ 이 TGF- $\beta 1$ 에 의해 유도된 MUC4/5AC 과생성과 상피중간엽 전이에 대한 억제효과를 스테로이드와의 비교를 통해 확인해보고자 하였으며, 이를 통해 염증성 호흡기 질환의 치 료제로서의 ginsenoside Rbl의 가능성을 알아보고자 하였다.

\section{재료 및 방법}

\section{세포 배양 및 처치}

NCI-H292 세포(American Type Culture Collection, Manassas, VA, USA)에 $100 \mathrm{U} / \mathrm{mL}$ penicillin, $100 \mu \mathrm{g} / \mathrm{mL}$ streptomycin, 10\% fetal bovine serum이 포함된 RPMI 1640 배지(Invitrogen, Carlsbad, CA, USA)를 이용하여 5\%의 이산 화탄소 조건 하에서 $37^{\circ} \mathrm{C}$ 의 온도로 배양하였다. 6-well plate 에 $1 \times 10^{6}$ cells/well의 밀도로 세포를 도포하여 배양하였다.

$\mathrm{Rb} 1$ 이 TGF- $\beta 1$ 에 의해 유도된 점액 유전자 발현과 세포연 접 단백의 발현 변화에 미치는 영향을 알아보기 위해서 NCIH292 세포에 각기 다른 농도의 Rbl(Sigma-Aldrich, St. Louis, $\mathrm{MO}, \mathrm{USA}$ )를 전처치한 후 1 시간 뒤에 $5 \mathrm{ng} / \mathrm{mL}$ 농도의 TGF$\beta 1(R \& D$ systems, Minnesota, MN, USA)를 투여하였다. 또
한 Rb1과 dexamethasone(Sigma-Aldrich, St. Louis, MO, USA)의 점액 유전자 발현 및 세포연접 단백 생성에 미치는 영향을 비교 관찰하기 위하여 NCI-H292 세포에 각기 다른 농도의 dexamethasone을 전처치한 후 1시간 뒤에 $5 \mathrm{ng} / \mathrm{mL}$ 농도의 TGF- $\beta 1$ 을 투여하였다. 처리 약제에 대한 NCI-H292 세포의 세포독성 유무는 WST-1 분석(EZ-CYTOX; Daeil Lab., Seoul, Korea)과 현미경을 이용한 세포 형태 변화 유 무를 확인하여 검증하였다. 본 연구에서 시행된 모든 실험은 3 개의 독립된 세포배지에서 3회 이상 반복된 실험을 통해 얻 은 결과로 분석하였으며, 본원 임상 시험 심사 위원회(Institutional Review Board)의 승인을 받아 시행하였다(YUMC 2017-07-015).

\section{Reverse transcription-polymerase chain reaction (RT-PCR) 분석}

$\mathrm{RNA}$ 에 대한 분석은 Gene Amp RNA PCR core kit와 MyCycler PCR(Bio-Rad, Hercules, CA, USA) 기계를 사 용하였다. $\mathrm{PCR}$ 에 사용된 기존연구에서 사용된 primer를 토 대로 제작하여 사용하였다(Table 1). RT-PCR 검사는 세포에 $0,5,10 \mu \mathrm{M}$ 농도의 Rb1 또는 $0,10 \mathrm{nM}$ 농도의 dexamethasone을 전처치한 후 1 시간 뒤에 $5 \mathrm{ng} / \mathrm{mL}$ 농도의 TGF- $\beta 1$ 을 투여하고, 8시간 후에 배양된 세포를 phosphate buffered saline로 3회 세척한 후 $\mathrm{mRNA}$ 를 추출하여 측정하였다.

\section{Real-time PCR 분석}

합성된 $\mathrm{cDNA} 0.5 \mu \mathrm{L}$ 를 대상으로 iQ SYBR Green $\mathrm{Su}^{-}$ permix(Bio-Rad)를 사용하여 real-time PCR을 수행하였다. Real-time PCR은 최종량이 $10 \mu \mathrm{L}$ 가 되게, $2.5 \mathrm{mM}$ 의 $\mathrm{MgCl}_{2}$ 와 그 최종 농도가 $0.5 \mu \mathrm{M}$ 이 되게 primer를 투여하였으며, $25 \mathrm{ng}$ 의 RNA $1 \mu \mathrm{L}$ 를 이용하여 실험을 수행하였다. 정량적인 PCR은 Light-Cycler(Bio-Rad)를 사용하여 측정하였다.

\section{Enzyme-linked immunosorbent assay(ELISA) 면역 분석법}

고분자인 MUC4와 MUC5AC 단백 생성을 측정하기 위해 서 ELISA법을 이용하였다. ELISA 검사는 세포에 $0,5,10 \mu \mathrm{M}$ 농도의 $\mathrm{Rbl}$ 또는 $0,10 \mathrm{nM}$ 농도의 dexamethasone을 전처치 한 후 1 시간 뒤에 $5 \mathrm{ng} / \mathrm{mL}$ 농도의 TGF- $\beta 1$ 을 투여하고, 24 시간 후에 배양된 세포에서 radioimmunoprecipitation assay buffer로 단백을 추출하였으며, ELISA reader(EL800 ${ }^{\circledR}$, BioTek Instruments, Inc., Winooski, VT, USA)로 $450 \mathrm{~nm}$ 에서 흡광도를 측정한 후 표준곡선을 이용하여 단백의 양을 정량하였다. 
Table 1. Primer used for polymerase chain reaction amplification

\begin{tabular}{|c|c|c|c|}
\hline Gene & Primary sequence & Annealing temperature $\left({ }^{\circ} \mathrm{C}\right)$ & Product size $(\mathrm{bp})$ \\
\hline \multirow[t]{2}{*}{$\overline{M U C 4}$} & F: 5'-TTCTAAGAACCACCAGACTCAGAGC-3' & 60 & 467 \\
\hline & R: 5'-GAGACACACCTGGAGAGAATGAGC-3' & & \\
\hline \multirow[t]{2}{*}{ MUC5AC } & F: 5'-TCA ACG GAG ACT GCG AGT ACA C-3' & 60 & 130 \\
\hline & R: 5'-CTT GAT GGC CTT GGA GCA-3' & & \\
\hline \multirow[t]{2}{*}{ Occludin } & F: 5'-TCA GGG AAT ATC CAC CTA TCA CTT CAG-3' & 55 & 189 \\
\hline & R: 5'-CAT CAG CAG CAG CCA TGT ACT CTT CAC-3' & & \\
\hline \multirow[t]{2}{*}{ Claudin 4} & F: 5'-AGC CTT CCA GGT CCT CAA CT-3' & 55 & 249 \\
\hline & R: 5'-AGC AGC GAG TCG TAC ACC TT-3' & & \\
\hline \multirow[t]{2}{*}{ Claudin 18} & F: 5'-TTC CAT CCC AGT ACC AAA GC-3' & 55 & 226 \\
\hline & R: 5'-CCG TTC TTT CCC CAG ACA TA-3' & & \\
\hline \multirow[t]{2}{*}{ E-cadherin } & F: 5'-CGCATTGCCACATACACTCT-3' & 60 & 252 \\
\hline & R: 5'-TTGGCTGAGGATGGTGTAAG-3' & & \\
\hline \multirow[t]{2}{*}{ N-cadherin } & F: 5'-AGTCAACTGCAACCGTGTCT-3' & 60 & 337 \\
\hline & R: 5'-AGCGTTCCTGTTCCACTCAT-3' & & \\
\hline \multirow[t]{2}{*}{ GAPDH } & F: 5'-CCTCCAAGGAGTAAGACCCC-3' & 60 & 145 \\
\hline & R: 5'-AGGGGTCTACATGGCAACTG-3' & & \\
\hline
\end{tabular}

GAPDH: glyceraldehyde-3-phosphate dehydrogenase

\section{Western blot 분석}

밀착연접단백인 occludin, claudin 4와 claudin 18과 접착 연접단백인 E-cadherin과 $\mathrm{N}$-cadherin 단백의 생성을 측정 하기 위해서 western blot법을 이용하였다. Western blot 검 사는 세포에 $0,5,10 \mu \mathrm{M}$ 농도의 $\mathrm{Rb} 1$ 또는 $0,10 \mathrm{nM}$ 농도의 dexamethasone을 전처치한 후 1 시간 뒤에 $5 \mathrm{ng} / \mathrm{mL}$ 농도의 TGF- $\beta 1$ 을 투여하여 배양하였다. 항체와의 비특이적 결합을 억제 시킨 후 세포연접단백들을 일차 항체로 각각 4시간 반 응시켰다. 이후 Tris-buffered saline와 Tween-20 buffer로 세척하고 이차 항체로 각각 1 시간 반응한 다음 세척하여 enhanced chemiluminescence reagent kit를 이용하여 각각의 단백의 띠(band)를 확인하였다. 확인된 띠의 세기는 Scion Image software(Scion Corporation, Frederick, MD, USA) 를 이용하여 반정량적으로 분석하여 상대적인 density로 나 타내었다.

\section{통계 분석}

통계 처리는 Windows용 SPSS version 21.0(IBM Corp., Armonk, NY, USA)를 사용하였다. 모든 실험은 3회 이상 시 행하였으며, $p$ 값이 0.05 미만인 경우를 유의한 것으로 정하여 Mann-Whitney U test를 이용하였다.

\section{결 과}

$\mathrm{Rb} 1$ 또는 Rb1과 $\mathrm{TGF}-\beta 1$ 복합 처치 시 $\mathrm{NCI}-\mathrm{H} 292$ 세포에 미치는 영향

WST법을 이용한 세포독성검사에서 $20 \mu \mathrm{M}$ 농도의 Rb1

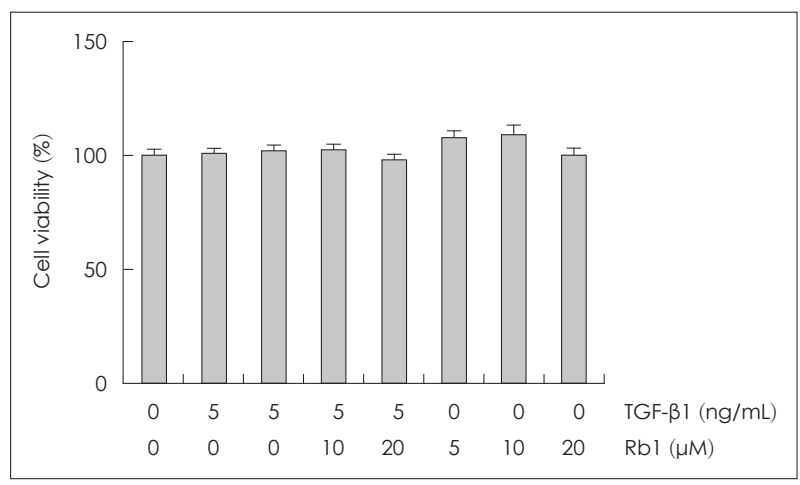

Fig. 1. Effects of Rb1 or Rb1 with TGF- $\beta 1$ on cell viability in $\mathrm{NCH}-$ $\mathrm{H} 292$ cells. Rb1 $(0,5,10$, or $20 \mu \mathrm{M})$ or Rb1 with TGF- $\beta 1$ ( 0 or $5 \mathrm{ng} /$ $\mathrm{mL}$ ) did not display significant cell killing activity up to $20 \mu \mathrm{M}$.

및 $5 \mathrm{ng} / \mathrm{mL}$ 농도의 TGF- $\beta 1$ 투여까지는 세포 독성이 관찰되 지 않았다(Fig. 1).

\section{$\mathrm{Rb} 1$ 이 TGF- $\beta 1$ 로 유도된 MUC4/5AC 발현에 미치는} 영향

$\mathrm{NCI}-\mathrm{H} 292$ 세포에서 TGF- $\beta 1$ 에 의해 유도되는 MUC4와 MUC5AC의 mRNA 발현 및 점액 단백 생성은 Rb1을 전처치 한 군에서 통계학적으로 의미있게 감소하였다. 또한 $\mathrm{mRNA}$ 발현 및 점액 단백 생성량 모두 고용량 $(10 \mu \mathrm{M})$ 을 투여한 군 에서 저용량 $(5 \mu \mathrm{M})$ 을 투여한 군보다 감소하는 경향을 보였 다(Fig. 2).

\section{$\mathrm{Rb} 1$ 이 TGF- $\beta 1$ 로 유도된 밀착연접단백의 발현변화에 미치는 영향}

$\mathrm{TGF}-\beta 1$ 이 occludin, claudin 4과 claudin 18의 발현에 미 


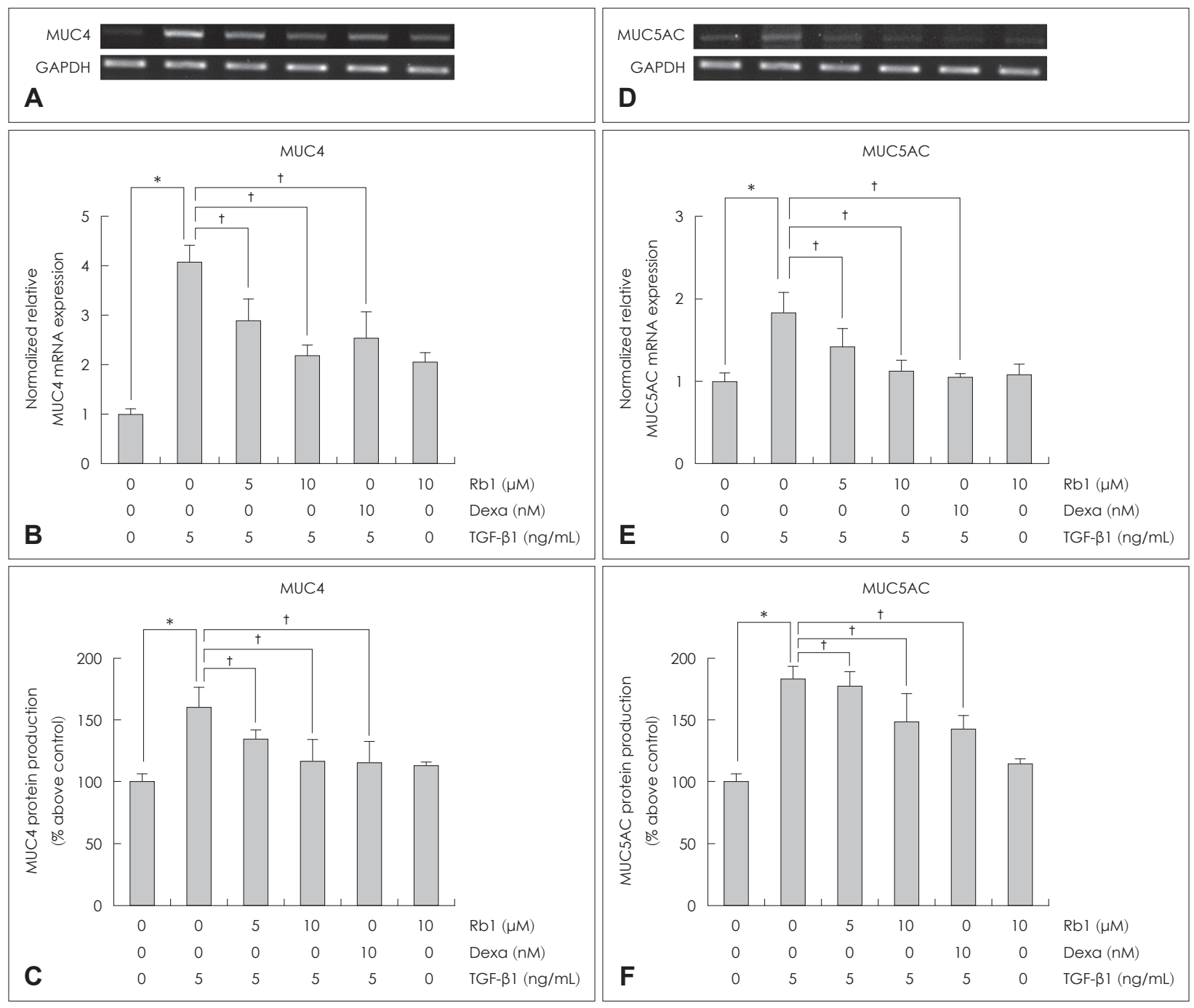

Fig. 2. The effects of Rb1 on TGF- $\beta 1$-induced MUC4/5AC expression in NCl-H292 cells. Reverse transcription-PCR (A, D), real-time PCR (B, E), ELISA (C, F). * $p<0.05$ compared with zero value, ${ }^{\dagger} p<0.05$ compared with TGF- $\beta 1$ ( $\left.5 \mathrm{ng} / \mathrm{mL}\right)$. GAPDH: glyceraldehyde3-phosphate dehydrogenase, Dexa: dexamethasone, PCR: polymerase chain reaction, ELISA: enzyme-linked immunosorbent assay.

치는 영향 및 Rb1이 TGF- $\beta 1$ 에 의해 유도된 밀착연접 단백의 발현변화에 미치는 영향을 확인해본 결과, TGF- $\beta 1$ 는 occludin과 claudin 18 의 mRNA 발현 및 단백 생성을 감소시켰으 나, Rb1또는 dexamethasone을 전처치한 군에서는 TGF- $\beta 1$ 에 의한 occludin과 claudin 18의 발현 감소가 나타나지 않았 다(Fig. $3 \mathrm{~A}-\mathrm{C}$ ). 또한 claudin 4 는 TGF- $\beta 1$ 의해 mRNA 발현 과 단백 생성이 증가하였으나, $\mathrm{Rb1}$ 또는 dexamethasone을 전처치한 군에서 $\mathrm{TGF}-\beta 1$ 에 의한 claudin 4 의 발현 증가가 의미있게 억제됨을 확인할 수 있었다(Fig. 3D-F).

\section{$\mathrm{Rb} 1$ 이 TGF- $\beta 1$ 로 유도된 접착연접단백의 발현변화에 미치는 영향}

$\mathrm{TGF}-\beta 1$ 가 E-cadherin과 N-cadherin의 발현에 미치는 영 향 및 $\mathrm{Rb} 1$ 이 TGF- $\beta 1$ 에 의해 유도된 접촉연접 단백의 발현변
화에 미치는 영향을 확인해본 결과, $\mathrm{TGF}-\beta 1$ 는 $\mathrm{E}-$ cadherin 의 발현을 감소시켰으며, $\mathrm{Rb1}$ 또는 dexamethasone을 전처 치한 군에서는 TGF- $\beta 1$ 에 E-cadherin의 발현 감소가 나타 나지 않았다(Fig. $4 \mathrm{~A}-\mathrm{C}$ ). 또한 TGF- $\beta 1$ 에 의해 N-cadherin 발현이 증가하였으며, $\mathrm{Rb1}$ 또는 dexamethasone을 전처치한 군에서 $\mathrm{TGF}-\beta 1$ 에 의한 $\mathrm{N}-$ cadherin의 과발현이 의미있게 억제됨을 확인할 수 있었다(Fig. 4D-F).

\section{고 찰}

인삼의 약리학적 효과를 나타내는 인삼 사포닌(ginseng saponin, ginsenoside)은 활성 산물 중 가장 중요한 성분이다. 그 구조에 따라 protopanaxadiol, protopanaxatriol, oleanole acid로 나눌 수 있으며, 그 종류는 100 개 이상으로 알려 


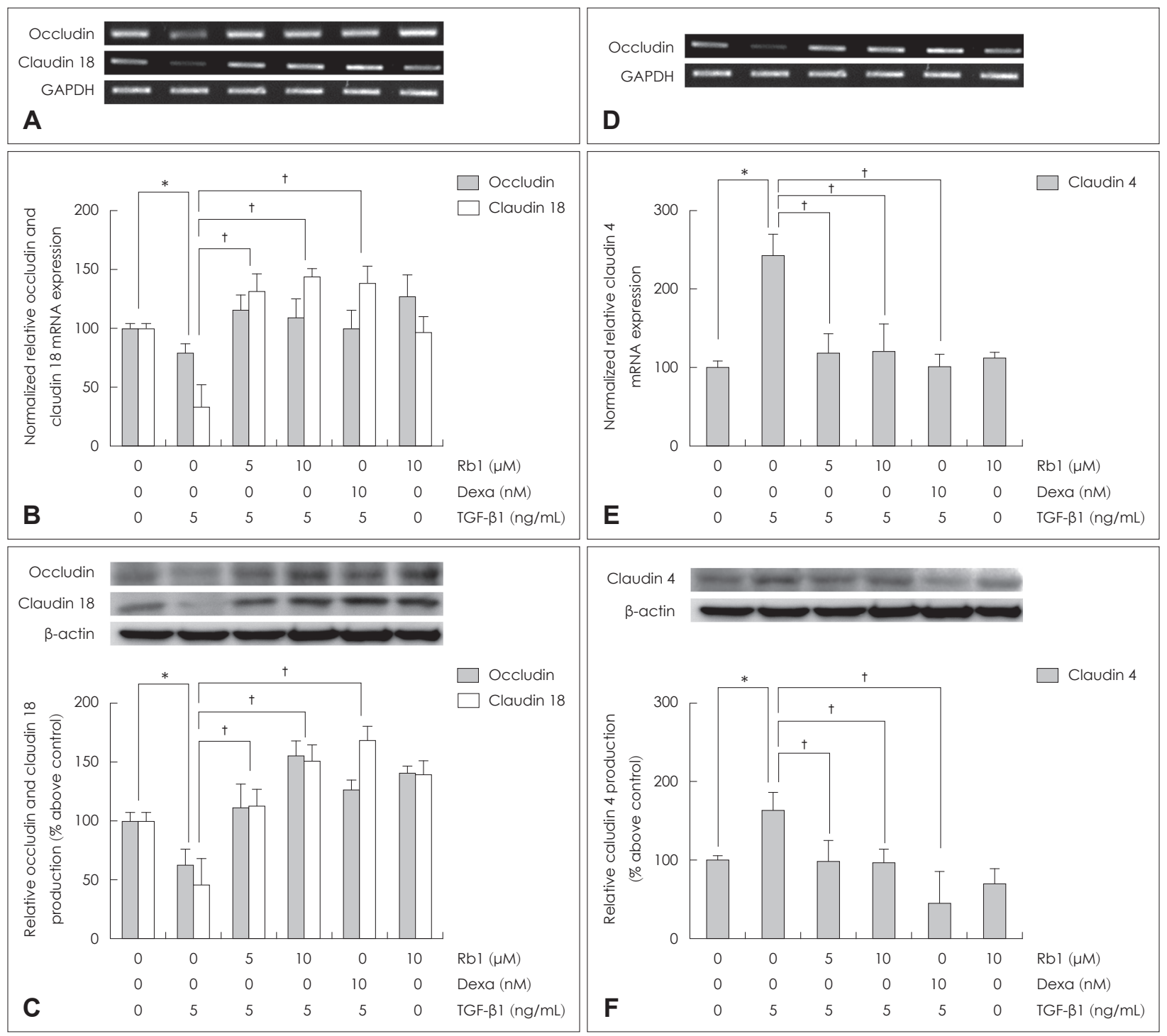

Fig. 3. The effects of Rb1 on TGF- $\beta 1$ - mediated expression level changes of tight junction molecules (occludin, claudin 4, and claudin 18) in $\mathrm{NCl}-\mathrm{H} 292$ cells. Reverse transcription-PCR $(\mathrm{A}, \mathrm{D})$, real-time PCR $(\mathrm{B}, \mathrm{E})$, western blot $(\mathrm{C}, \mathrm{F}) .{ }^{*} p<0.05$ compared with zero value, $+p<0.05$ compared with TGF- $\beta 1$ (5 ng/mL). GAPDH: glyceraldehyde-3-phosphate dehydrogenase, Dexa: dexamethasone, PCR: polymerase chain reaction.

져 있다. 그 중 protopanaxadiol은 총 19개의 종류가 존재하 며, $\mathrm{Rb} 1, \mathrm{Rb} 2, \mathrm{Rc}, \mathrm{Rd}$ 가 대표적으로 알려져 있다. ${ }^{14,15)}$ 최근 다 양한 연구에서 염증성 호흡기 질환에 대한 인삼 사포닌의 치 료효과가 보고되고 있다. ${ }^{16-18)} \mathrm{Jung}$ 등(1)의 연구에서는 알레르 기성 비염환자에서 홍삼이 코막힘을 포함한 비염환자의 삶의 질 척도가 호전된다고 보고하였으며, Lee 등기 의 연구에서는 $\mathrm{A} 549$ 세포와 천식환자의 폐조직에서 인삼의 사포닌 성분 중 하나인 Rg3이 interleukin(IL)-4, TNF- $\alpha$, eotaxin 등을 의 미있게 감소시키며, IL-1 $1 \beta$ 에 의해 유도된 COX-2의 활성화를 억제한다는 것을 보고하였다. 또한 Shergis 등 ${ }^{18}$ 의 연구에는 $\mathrm{Rb} 1$ 이 만성폐쇄성 폐질환의 염증성 반응 과정의 주된 신호 전달체계로 알려진 TNF, IL-6, IL-8 등의 사이토카인의 활
성화 과정을 억제하며, 산화적 스트레스를 일으키는 주된 요 소인 활성산소, 산화질소 등의 발생과정을 억제하는 것으로 보고하였다. 그러나 아직까지 Rb1이 염증성 호흡기 질환의 호전에 미치는 영향과 명확한 기전에 대한 확인이 부족한 실 정이다.

점액유전자는 $\mathrm{TGF}-\beta 1$ 과 $\mathrm{IL}$ 등의 다양한 사이토카인과 lipopolysaccharide(LPS)와 같은 외부독성물질에 의해 과발 현 유도되는 것으로 보고되고 있다..$^{15,19-21)}$ 본 연구진이 사포닌 의 점액 과분비 억제효과를 확인하기 위해 시행한 이전 연구 에서도 LPS에 의해 MUC5AC 점액 유전자의 과발현이 유도 되었으며, 사포닌의 성분 중 하나인 protopanaxadiol이 활성 화 산소의 억제를 통해 LPS에 의해 유도된 MUC5AC의 과 


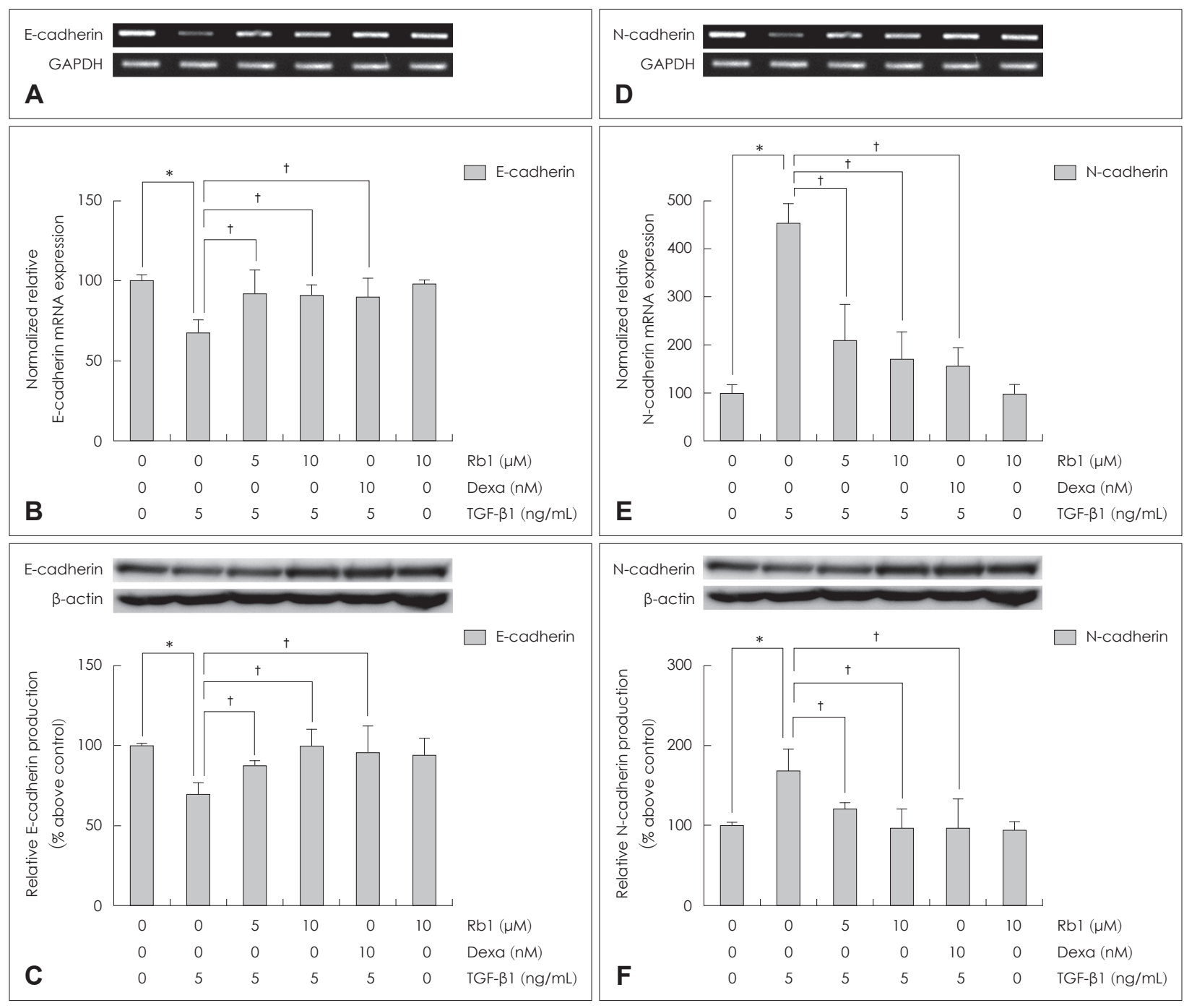

Fig. 4. The effects of Rb1 on TGF- $\beta 1$ - mediated expression changes of cell adhesive molecules (E-cadherin and $\mathrm{N}$-cadherin) in $\mathrm{NCl}$ $\mathrm{H} 292$ cells. Reverse transcription-PCR (A, D), real-time PCR $(B, E)$, western blot $(C, F) .{ }^{*} p<0.05$ compared with zero value, $+p<0.05$ compared with TGF- $\beta 1$ (5 ng/mL). GAPDH: glyceraldehyde-3-phosphate dehydrogenase, Dexa: dexamethasone.

발현을 줄인다는 것을 확인할 수 있었다. ${ }^{15)}$ 본 연구에서도 $\mathrm{NCI}-\mathrm{H} 292$ 세포에서 TGF- $\beta 1$ 의 유도된 MUC4/5AC 점액유 전자의 과발현을 $\mathrm{Rb} 1$ 이 의미있게 억제함을 확인할 수 있었 으며, 이는 중요한 염증성 호흡기질환 치료제인 dexamethasone과 유사한 정도의 억제효과가 있음을 확인할 수 있었다.

기도 상피세포는 다양한 사이토카인과 외부독성물질들에 의해 세포 연접 구조가 손생될 때 상피-중간엽 전이가 관찰 되고, 이때 다양한 세포 결합 단백들의 발현변화가 관찰된다. 상피-중간엽 전이 때는 occludin, claudin $18, \mathrm{E}$-cadherin, ZO-1, cytokeratin과 같은 세포결합 단백들의 발현억제가 관찰되며, claudin 4, N-cadherin, fibronectin, vimentin과 같은 단백들의 발현의 증가가 나타난다. ${ }^{5-7)}$ 최근 다양한 연구 에서 상피-중간엽 전이가 천식과 만성폐쇄성 폐질환과 같은 염증성 호흡기 질환의 악화에 중요한 병인으로 보고되고 있
다. ${ }^{7-9,22,23)}$ Hackett ${ }^{7}$ 은 외부물질의 노출로 인해 발생한 성장인 자, 염증성 사이토카인, 모세포 단백질(matricellular protein) 등이 상피-중간엽 전이를 유발하며 이러한 과정이 천식환자 의 기도 리모델링의 원인 중 하나로 보고하였으며, $\mathrm{Hou}$ 등은 최근 연구들의 리뷰를 통해 흡연으로 인해 유발되는 만성폐 쇄성 폐질환과 폐암의 중요한 발병기전으로서 상피-중간염 전이의 중요성을 보고하였다. 최근 TGF- $\beta 1$ 에 의해 유도되는 상피-중간엽 전이를 억제 할 수 있는 물질들에 대한 다양한 연구가 이루어지고 있으며, 항염증제로서 효과가 알려진 dexamethasone이 TGF- $\beta 1$ 에 의해 유도된 상피-중간엽 전이를 억제하는 역할을 하는 것으로 알려져 있다.11,22-25) 본 연구에 서도 NCI-H292 세포에서 TGF- 11 에 의해 유도된 상피-중 간엽 전이 과정 중 억제되는 ocluddin, claudin $18, \mathrm{E}-\mathrm{cad}^{-}$ herin mRNA와 단백 생성을 유의하게 증가시켰고, TGF- $\beta 1$ 
에 의해 유도된 상피-중간엽 전이 과정 중 유도되는 claudin 4, $\mathrm{N}$-cadherin mRNA와 단백 생성을 유의하게 억제하였다. 이 를 통해 $\mathrm{TGF}-\beta 1$ 에 의해 유도된 상피-중간엽 전이를 Rb1이 효과적으로 억제할 수 있음을 확인할 수 있었다.

본 연구에서 우리는 Rb1이 TGF- $\beta 1$ 에 의해 유도된 MUC4/ $5 \mathrm{AC}$ 과발 및 상피-중간엽 전이 관련 세포연접 단백들의 발 현을 의미있게 조절한다는 것을 확인할 수 있었다. 이는 염증 성 호흡기 질환의 새로운 치료제로서의 Rb1의 가능성과 스 테로이드의 대체약제로서의 가능성을 모두를 보여준 결과로 생각된다. $\mathrm{Rb} 1$ 의 항염증 효과의 관련 기전으로는 면역 염증 반응의 주요 조절 인자인 nuclear factor-kappa $\mathrm{B}(\mathrm{NF}-\mathrm{kB})$ 의 활성화와 mitogen-activated protein kinases(MAPKs)의 활성화에 대한 억제효과로 생각해볼 수 있으며, ${ }^{11)}$ 이는 스테 로이드의 항염증 효과의 관련기전으로도 알려져 있다. ${ }^{22,23)}$ 또 한 다양한 $\mathrm{MAPKs}$ 와 $\mathrm{NF}-\mathrm{kB}$ 의 활성화는 점액 유전자 과발 현과 $\mathrm{EMT}$ 발생의 중요 조절 기전으로도 알려져 있어 Rb1의 $\mathrm{MAPKs}$ 와 $\mathrm{NF}-\mathrm{kB}$ 의 활성화 억제를 통해 점액 유전자의 과 발현과 EMT 반응의 억제를 유도하는 것으로 생각해볼 수 있 다. ${ }^{26,27)}$ 그러나 $\mathrm{Rb} 1$ 이 점액 과분비 조절억제의 정확한 기전과 위치를 확인하기 위해서는 air-liquid interface 기법 또는 ex vivo 법을 이용한 추가 실험이 필요할 것으로 생각되며, 세 포-중간엽 전이 조절 효과에 대한 상세한 기전에 대한 추가 연구도 필요할 것으로 생각된다. 또한, $\mathrm{Rb} 1$ 의 복용량과 혈중 농도에 대해 동물실험 및 임상연구를 통한 추가 연구도 필요 할 것으로 생각된다.

\section{Acknowledgments}

This research was supported by Basic Science Research Program through the National Research Foundation of Korea (NRF) funded by the Ministry of Education (NRF-2017R1D1A3B03029607).

\section{Author Contribution}

Conceptualization: Tae Yeong Choi, Chang Hoon Bae. Data curation: Tae Yeong Choi, Joon-Hee Kim. Formal analysis: Hyung-Gyun $\mathrm{Na}$, Si-Youn Song, Yong-Dae Kim. Funding acquisition: Chang Hoon Bae. Investigation: Tae Yeong Choi, Sooyeon Jo, Sangjae Lee. Methodology: Yoon Seok Choi, Yong-Dae Kim. Writing_-original draft: Tae Yeong Choi, Chang Hoon Bae. Writing - review \& editing: Tae Yeong Choi, Yoon Seok Choi, Chang Hoon Bae.

\section{ORCIDs}

Chang Hoon Bae

Yoon Seok Choi

Si-Youn Song

Yong-Dae Kim https://orcid.org/0000-0002-0835-4060

https://orcid.org/0000-0002-0616-7122

https://orcid.org/0000-0001-6642-8841

https://orcid.org/0000-0003-0501-966X

\section{REFERENCES}

1) Ali MS, Pearson JP. Upper airway mucin gene expression: A review. Laryngoscope 2007;117(5):932-8.
2) Rose MC, Voynow JA. Respiratory tract mucin genes and mucin glycoproteins in health and disease. Physiol Rev 2006;86(1):245-78.

3) Chaturvedi P, Singh AP, Batra SK. Structure, evolution, and biology of the MUC4 mucin. FASEB J 2008;22(4):966-81.

4) Hattrup CL, Gendler SJ. Structure and function of the cell surface (tethered) mucins. Annu Rev Physiol 2008;70:431-57.

5) Tsukita S, Furuse M, Itoh M. Multifunctional strands in tight junctions. Nat Rev Mol Cell Biol 2001;2(4):285-93.

6) Xu J, Lamouille S, Derynck R. TGF-beta-induced epithelial to mesenchymal transition. Cell Res 2009;19(2):156-72.

7) Hackett TL. Epithelial-mesenchymal transition in the pathophysiology of airway remodelling in asthma. Curr Opin Allergy Clin Immunol 2012;12(1):53-9.

8) Hou W, Hu S, Li C, Ma H, Wang Q, Meng G, et al. Cigarette smoke induced lung barrier dysfunction, EMT, and tissue remodeling: A possible link between COPD and lung cancer. Biomed Res Int 2019;2019:2025636.

9) Ijaz T, Pazdrak K, Kalita M, Konig R, Choudhary S, Tian B, et al. Systems biology approaches to understanding epithelial mesenchymal transition (EMT) in mucosal remodeling and signaling in asthma. World Allergy Organ J 2014;7(1):13.

10) Adcock IM, Ito K. Glucocorticoid pathways in chronic obstructive pulmonary disease therapy. Proc Am Thorac Soc 2005;2(4):313-9; discussion 340-1.

11) Kim JH, Yi YS, Kim MY, Cho JY. Role of ginsenosides, the main active components of Panax ginseng, in inflammatory responses and diseases. J Ginseng Res 2017;41(4):435-43.

12) Sun K, Wang CS, Guo J, Horie Y, Fang SP, Wang F, et al. Protective effects of ginsenoside Rb1, ginsenoside Rg1, and notoginsenoside $\mathrm{R} 1$ on lipopolysaccharide-induced microcirculatory disturbance in rat mesentery. Life Sci 2007;81(6):509-18.

13) Wang CZ, Du GJ, Zhang $Z$, Wen $X D$, Calway $T$, Zhen $Z$, et al. Ginsenoside compound $\mathrm{K}$, not $\mathrm{Rb} 1$, possesses potential chemopreventive activities in human colorectal cancer. Int J Oncol 2012;40(6):1970-6.

14) Bai L, Gao J, Wei F, Zhao J, Wang D, Wei J. Therapeutic potential of ginsenosides as an adjuvant treatment for diabetes. Front Pharmacol 2018;9:423.

15) Song YS, Kim JH, Na HG, Choi YS, Song SY, Kim YD, et al. Inhibitory effects of protopanaxadiol on lipopolysaccharide-induced reactive oxygen species production and MUC5AC expression in human airway epithelial cells. Korean J Otorhinolaryngol-Head Neck Surg 2019;62(9):507-14.

16) Jung JW, Kang HR, Ji GE, Park MS, Song WJ, Kim MH, et al. Therapeutic effects of fermented red ginseng in allergic rhinitis: A randomized, double-blind, placebo-controlled study. Allergy Asthma Immunol Res 2011;3(2):103-10.

17) Lee IS, Uh I, Kim KS, Kim KH, Park J, Kim Y, et al. Antiinflammatory effects of ginsenoside $\mathrm{Rg} 3$ via $\mathrm{NF}-\kappa \mathrm{B}$ pathway in A549 cells and human asthmatic lung tissue. J Immunol Res 2016; 2016:7521601.

18) Shergis JL, Di YM, Zhang AL, Vlahos R, Helliwell R, Ye JM, et al. Therapeutic potential of Panax ginseng and ginsenosides in the treatment of chronic obstructive pulmonary disease. Complement Ther Med 2014;22(5):944-53.

19) Jang YJ, Kwon HJ, Wang JW, Lee BJ, Chung YS. Rhinovirusinduced mucin gene expression in airway epithelial cells. Korean J Otorhinolaryngol-Head Neck Surg 2009;52(8):670-3.

20) Lee JG, Moon HJ, Kim, SS, Kim CW, Yoon JH. Expression and regulation of MUC8 \& MUC5AC by various cytokines in normal human nasal epithelial cells. Korean J Otolaryngol 2001;44(6):600-5.

21) Park CH, Song YS, Bae CH, Choi YS, Song SY, Shin KC, et al. Asian sand dust up-regulates MUC4 expression in human upper airway epithelial cells. Korean J Otorhinolaryngol-Head Neck Surg 2017;60(5):222-31. 
22) Yang HW, Lee SA, Shin JM, Park IH, Lee HM. Glucocorticoids ameliorate TGF- $\beta 1$-mediated epithelial-to-mesenchymal transition of airway epithelium through MAPK and Snail/Slug signaling pathways. Sci Rep 2017;7(1):3486.

23) Doerner AM, Zuraw BL. TGF-betal induced epithelial to mesenchymal transition (EMT) in human bronchial epithelial cells is enhanced by IL-1beta but not abrogated by corticosteroids. Respir Res 2009;10(1):100.

24) Liu J, Li YY, Andiappan AK, Yan Y, Tan KS, Ong HH, et al. Role of IL-13R $\alpha 2$ in modulating IL-13-induced MUC5AC and ciliary changes in healthy and CRSwNP mucosa. Allergy 2018;73(8):167385.

25) Hauber HP, Goldmann T, Vollmer E, Wollenberg B, Zabel P. Effect of dexamethasone and ACC on bacteria-induced mucin expression in human airway mucosa. Am J Respir Cell Mol Biol 2007;37(5): 606-16.

26) Bae CH, Choi YS, Na HG, Song SY, Kim YD. Interleukin (IL) 36 gamma induces mucin 5AC, oligomeric mucus/gel-forming expression via IL-36 receptor-extracellular signal regulated kinase 1 and 2, and p38-nuclear factor kappa-light-chain-enhancer of activated B cells in human airway epithelial cells. Am J Rhinol Allergy 2018;32(2):87-93.

27) Li X, Yan X, Wang Y, Wang J, Zhou F, Wang H, et al. NLRP3 inflammasome inhibition attenuates silica-induced epithelial to mesenchymal transition (EMT) in human bronchial epithelial cells. Exp Cell Res 2018;362(2):489-97. 